\title{
PENGARUH METODE PEMBELAJARAN DAN TIPE PENGASUHAN ORANG TUA TERHADAP KETERAMPILAN SOSIAL (STUDI EKSPERIMEN PADA TAMAN KANAK- KANAK DI PALU SULAWESI TENGAH)
}

\author{
Andi Agusniatih \\ Jurusan PG-PAUD Universitas Tadulako, Jln. Soekarno Hatta, Palu, Sulawesi Tengah. \\ E-mail: andiagusniatih@gmail.com, Telp: 081241254385
}

\begin{abstract}
Abstrak
Penelitian ini bertujuan untuk mengetahui pengaruh metode pembelajaran dan tipe pengasuhan orang tua terhadap keterampilan sosial anak pada sekolah TK Kota Palu. Sampel terdiri dari 80 anak TK yang diambil dengan random sampling sederhana dengan desain faktorial $2 \times 2$. Hasil temuan dalam penelitian ini adalah: (1) hasil keterampilan sosial anak usia dini untuk kelompok anak yang diberi metode pembelajaran kooperatif, lebih tinggi dari kelompok anak yang diberi metode pembelajaran kompetitif, (2) hasil keterampilan sosial anak usia dini untuk kelompok anak yang memiliki tipe pengasuhan orang tua dengan kategori autoritatif, lebih tinggi dari kelompok tipe pengasuhan orang tua kategori permisif, (3) terdapat pengaruh interaksi antara faktor tipe pengasuhan orang tua dengan metode pembelajaran terhadap keterampilan sosial anak usia dini, (4) khusus tipe pengasuhan orang tua kategori autoritatif, hasil keterampilan sosial anak usia dini dalam kelompok metode pembelajaran kooperatif lebih tinggi dari kelompok pembelajaran kompetitif, dan (5) khusus tipe pengasuhan orang tua kategori permisif, hasil keterampilan sosial anak usia dini dalam kelompok metode pembelajaran kooperatif lebih tinggi dari kelompok pembelajaran kompetitif.
\end{abstract}

Kata kunci: Keterampilan Sosial, Metode Pembelajaran, dan Tipe Pengasuhan Orang Tua.

\section{THE EFFECTS OF TEACHING METHODS AND PARENTING TYPES ON CHILDREN SOCIAL SKILLS (EXPERIMENTAL STUDY AT KINDERGARTEN IN THE CITY OF PALU CENTRAL SULAWESI)}

\begin{abstract}
This study aimed to examine the effects of teaching methods and parenting types on children social skills at kindergarten in the city of Palu. The sample consisted of 80 kindergarten children, taken by simple randomsampling with a $2 \times 2$ factorial design. The result of this study showed that: (1) early-aged children social skills were higher when taught using a cooperative learning method compared to a competitive learning method; (2) early-aged children social skills were higher when taught with a parenting type authoritative category than with a parenting typeof permissive category; (3) there was interaction effect between the factors of parenting types and learning method on social skills of early-aged children; (4) with a parenting type of authoritative category, the group of earlyaged children had highersocial skills when they were taught using a cooperative learning method compared to a competitive learning method; and (5) with a parenting type of permissive category, early-aged children had higher social skills when they were taught using a cooperative learning method compared to a competitive learning method.
\end{abstract}

Keywords: Social Skills, Learning Methods, And Parenting Types

\section{PENDAHULUAN}

Problematika pendidikan yang terjadi di Indonesia saat ini, salah satunya adalah proses belajar mengajar yakni kurangnya kemampuan pendidik dalam menstimulasi perkembangan emosi dan sosial anak. Pembelajaran yang diberikan terlalu berorentasi sangat sempit yang berpusat pada aspek kognitif atau pengetahuan, sehingga pendidikan yang diberikan tidak mampu menghasilkan kepribadian secara utuh 
karena kehilangan unsur pundamentalnya yang berakar pada nilai-nilai sosial, etika, moral maupun spiritual.

Manusia dikatakan sebagai makhluk sosial karena manusia membutuhkan satu sama lain. Manusia hidup adalah untuk berinteraksi dengan orang lain. Dalam berinteraksi antar manusia memerlukan keterampilan, salah satunya adalah keterampilan sosial.

Keterampilan sosial menurut Rogers (1995: 64) adalah kemampuan anak untuk mengelolah lingkungannya di dalam bekerja sama, tolong-menolong, berbagi dan sukses memecahkan masalah sosial. Combs dalam Hargie (2006: 10-12) mengutip beberapa definisi keterampilan sosial antara lain: keterampilan sosial adalah kemampuan untuk berinteraksi dengan orang lain, dalam konteks sosial dengan cara-cara khusus yang dapat diterima oleh lingkungan, dan pada saat bersamaan dapat bermanfaat secara pribadi, bermanfaat secara bersama atau dapat bermanfaat bagi orang lain.

Morrison (2012: 228) keterampilan interpersonal disebut juga sebagai keterampilan sosial yakni keterampilan antarpribadi yang mencakup bergaul dan bekerjasama dengan orang lain, mempelajari dan menggunakan tata krama. Sementara Johnson and Johnson (1999 : 82-84), mendefinisikan bahwa keterampilan sosial merupakan pengetahuan keterampilan antar pribadi, kemampuan untuk membangun hubungan dan menjaga hubungan yang positif dengan orang lain, sikap, motivasi orang lain tentang apa yang dikatakan dan dilakukannya, dan kemampuan untuk berkomunikasi dengan jelas dan efektif, serta kemampuan membangun hubungan yang efektif dan kooperatif.

Berdasarkan pemaparan tersebut, dapat disimpulkan bahwa yang dimaksud dengan keterampilan sosial dalam penelitian ini adalah kemampuan anak dalam berinteraksi dengan lingkungan sebayanya baik lisan maupun non lisan dengan sasaran pengembangan keterampilan sosial yakni: a) anak mampu berempati dengan teman; b) anak mampu bekerjasama dengan teman; c) anak mampu berkomunikasi dengan teman; d) anak mampu mengontrol diri dengan mengendalikan emosi; e) anak mampu bertanggung jawab dengan menyelesaikan tugas sampai selesai.

Hasil observasi dari 28 lembaga pendidikan Taman Kanak-Kanak di Kota Palu, Keterampilan sosial kurang dikembangkan. Pada umumnya lembaga TK tersebut, pembelajaran yang diberikan guru kepada anak, sangat bergantung pada buku paket yang dikerjakan anak setiap hari. Proses belajar mengajar di TK menggunakan suasana belajar individual, kompetitif dan kurang menerapkan metode pembelajaran kooperatif. Di samping itu pula, adanya tuntutan dari orang tua yang menginginkan anaknya, setelah tamat TK anak dapat membaca, berhitung dan menulis. Hal inilah yang menyebabkan, perkembangan dan keterampilan sosial anak kurang dikembangkan bahkan cenderung terabaikan. Sebagai contoh, nilai yang mementingkan kebersamaan, semakin pudar dan digeser oleh nilai kompetitif yang individualistis.

Keterampilan sosial yang diberikan melalui penerapan pembelajaran kooperatif sangat penting diberikan pada anak. May Lwin dkk (2008: 197) bahwa keterampilan sosial itu sesuatu yang harus dikembangkan melalui pembinaan dan pengajaran. Anak yang sejak dini ditanamkan atau diajarkan keterampilan sosial, akan mudah menjalin hubungan yang baik dengan lingkungannya.

Rogers dan Sawyers (1995: 64) menyatakan bahwa keterampilan sosial adalah kemampuan anak-anak untuk mengelolah lingkungannya di dalam bekerjasama, tolongmenolong, berbagi dan sukses memecahkan masalah sosial. Keterampilan sosial ini merupakan hal yang harus dipahami dan diajarkan karena anak merupakan makhluk sosial yang akan hidup bermasyarakat. Peran pendidik dan pengasuhan orang tua yang baik, mempunyai peran dan andil yang sangat besar di dalam peningkatan keterampilan sosial anak. Teori behaviorisme meyakini bahwa anak tidak bisa dengan sendirinya mengembangkan keterampilan sosialnya, melainkan membutuhkan keteladan orang dewasa dan pembiasaan sehari-hari dalam pembentukan perilaku sosialnya

Oleh karena itu, peneliti tertarik melakukan penelitian eksperimen sebagai salah satu wujud untuk memperbaiki kondisi sosial dan kondisi pendidikan TK saat ini dengan menerapkan metode pembelajaran yakni metode pembelajaran kooperatif dan kompetitif serta tipe pengasuhan orang tua yakni autoritatif dan permisif. Kedua metode pembelajaran tersebut akan diteliti pengaruhnya terhadap hasil belajar keterampilan sosial anak.

Metode dalam kamus besar Bahasa Indonesia berasal dari bahasa Yunani yaitu methodos yang berasal dari kata "meta" berarti 
melalui, dan " hodos." berarti jalan, sehingga metode berarti jalan yang harus dilalui, cara melakukan sesuatu atau prosedur. Jadi metode diartikan sebagai cara teratur yang digunakan untuk melaksanakan suatu pekerjaan agar tercapai sesuai yang dikehendaki

Metode pembelajaran menurut Gerlach dan Ely (2008: 8) mendefinisikan metode kaitannya dengan pembelajaran sebagai suatu rancangan yang sistematis untuk menyampaikan informasi. Dengan demikian metode pembelajaran adalah suatu pengetahuan tentang cara atau upaya yang dilakukan oleh guru secara sistematis, di dalam menyajikan, menguraikan, memberikan contoh dan memberikan latihan isi pelajaran kepada anak, baik secara kelompok maupun secara kompetitif, agar pelajaran, dapat diserap, dipahami, dan dimanfaatkan oleh anak dengan baik.

Pembelajaran kooperatif menurut Sherman dalam Santrock (2008: 397) menyatakan pembelajaran kooperatif terjadi ketika anak bekerjasama dalam kelompok kecil (kelompok belajar) yang terdiri empat orang untuk saling membantu dalam belajar. Sementara Rich dkk dalam Goodwin (1999 : 29) mengatakan bahwa pembelajaran kooperatif merupakan pengaturan mengajar yang merujuk kepada kelompok anak yang heterogen dan kecil yang bekerjasama untuk mencapai sasaran belajar yang umum dan hubungan kolaboratif diantara para peserta. Metode pembelajaran kooperatif (learning together) yang dikemukakan Johnson and Johnson (1999: 5) adalah bekerja secara bersama untuk menyelesaikan tugas yang dibagi secara bersama. Di dalam situasi yang kooperatif, individu mencari hasil yang bermanfaat bagi mereka sendiri dan bermanfaat bagi semua anggota lainnya.

Selvarajah (2010: 114) mengatakan bahwa struktur-struktur sasaran yang kooperatif beroperasi, ketika dua individu atau lebih berada dalam sebuah situasi membantu orang lain untuk diberikan penghargaan. Atribut lain yang dianggap penting dalam mendefinisikan struktur sasaran yang kooperatif adalah interaksi tatap muka, pengelompokan-pengelompokan yang heterogen, akuntabilitas individual, pemrosesan grup, dan saling ketergantungan yang positif. Saling Ketergantungan positif dirasakan anak ketika melakukan suatu pekerjaan, mengadakan sumber belajar dan berbagi peran demi tercapainya tujuan yang diharapkan. Dalam mencapai tujuan itu, terjadi interaksi tatap muka berupa dialog sesama teman dengan guru.

Berdasarkan beberapa definisi tersebut, maka metode pembelajaran kooperatif dalam penelitian eksperimen ini adalah pembelajaran kooperatif di mana anak bekerja secara bersama untuk menyelesaikan tugas yang dibagi secara bersama, yang menempatkan anak dalam kelompok heterogen, yang dilaksanakan selama beberapa minggu atau bulan dengan arahan dan bimbingan guru.

Johnson dan Johnson (1999: 3) mengatakan bahwa metode pembelajaran kompetitif adalah metode yang menekankan pentingnya pemberian reward kepada anak. Ketika anak berhasil menyelesaikan tugasnya, maka anak diberi reward sebagai tanda keberhasilan yang telah diraihnya. Rewardreward ini memicu anak untuk berbuat yang lebih baik lagi, demi tercapainya tujuan belajar yang diharapkan.

Karakterisitik kompetitif diantaranya adalah adanya ketergantungan negatif antar anak, adanya pertarungan yang satu pemenang dan yang lainnya tidak. Dalam suasana belajar ini hanya ada satu pemenang yang bernilai tinggi dibandingkan dengan anak yang lainnya. Meski memuat unsur kompetisi, strategi pembelajaran ini cocok digunakan bagi anak yang memiliki tipe belajar individual. Konsentrasi penuh bisa dicapai jika seorang anak belajar dengan kekuatan dan kreativitasnya sendiri tanpa melibatkan keikutsertaan orang lain dalam menyelesaikan tugas belajar. Muatan kompetisi terlihat sejak awal perencanan pembelajaran sampai tahap evaluasi. Langkah pembelajaran yang ditempuh dimulai dengan merencanakan aktivitas apa yang akan dikerjakan anak sesuai dengan tujuan yang sudah ditetapkan.

Berdasarkan definisi tersebut di atas, maka metode pembelajaran kompetitif dalam penelitian ini adalah pembelajaran yang tidak memuat unsur ketergantungan antar anak dalam mencapai tujuan pembelajaran. Masing-masing anak berkompetisi memperebutkan posisi sebagai pemenang. Mereka yang menang akan diberikan reward yang sesuai dengan prestasinya.

Tipe pengasuhan Menurut Hurlock (1992: 205) merupakan metode yang dipilih orang tua sebagai metode pendidikan anak, sebagian bergantung pada cara mereka dibesarkan, sebagian pada pengalaman pribadi atau teman dan menghasilkan apa yang diinginkan anak 
kelak. Berbeda dengan tipe pengasuhan dari Santoso (2004: 125) adalah cara pendekatan orang dewasa kepada anak dalam memberikan bimbingan, arahan, pengaruh, dan pendidikan, supaya anak menjadi dewasa dan mampu berdiri sendiri.

Ada empat tipe/gaya pengasuhan orang tua menurut Baumrind dalam Santrock (2008: 91) yakni: 1) Authoritarian parenting adalah tipe asuh yang bersifat membatasi dan menghukum. Orang tua yang otoriter memerintahkan anak untuk mengikuti petunjuk mereka dan menghormati mereka. Mereka membatasi dan mengontrol anak mereka dan tidak mengizinkan anak banyak cakap; 2), Authoritative parenting stayle, mendorong anaknya untuk menjadi independen tetapi masih membatasi dan mengontrol tindakan anaknya. Perbincangan tukar pendapat diperbolehkan dan orang tua bersikap membimbing dan mendukung; 3) neglectful parenting stayle adalah tipe asuh di mana orang tua tidak terlibat aktif dalam kehidupan anaknya; 4). Indulgent parenting stayle adalah tipe asuh di mana orang tua sangat terlibat dalam kehidupan anaknya tapi tidak banyak memberi batasan atau kekangan pada perilaku mereka.

Dari keempat tipe pengasuhan yang dikemukakan oleh Baumrind, hanya ada dua tipe pengasuhan orang tua berdasarkan karakteristik yang dimiliki oleh anak pada Tk Madani dan Tk Pembina, yakni tipe pengasuhan autoritatif dan tipe pengasuhan permisif.

\section{METODE}

Metode penelitian yang digunakan adalah metode eksperimen dengan desain faktorial 2X2. Dalam desain ini terdapat tiga variable yaitu variabel respon $(\mathrm{Y})$ adalah keterampilan sosial anak usia dini. Sedangkan faktor perlakuannya adalah (1) metode pembelajaran (A) yang diklasifikasikan menjadi dua level yaitu metode kooperatif (A1) dan metode kompetitif (A2), dan (2) tipe pengasuhan orang tua (B), yang masing-masing mempunyai dua tingkat perlakuan dan merupakan treatment by level yaitu tipe pengasuhan autoritatif (B1) dan tipe pengasuhan permisif (B2).

Proses pengambilan sampel dilakukan dengan teknik random sampling. Analisis data yang digunakan dalam penelitian ini meliputi analisis deskriptif, analisis terhadap uji persyaratan, dan analisis inferensial. Ketiga analisis ini dilakukan berdasarkan data keterampilan sosial anak usia dini setelah perlakuan metode pembelajaran dan tipe pengasuhan orang tua.

Teknik analisis varians (ANAVA) digunakan untuk mengetahui pengaruh metode pembelajaran dan tipe pengasuhan orang tua terhadap keterampilan sosial anak

\section{HASIL DAN PEMBAHASAN}

1. Hasil keterampilan sosial anak untuk kelompok anak yang diberi metode pembelajaran kooperatif $\left(A_{1}\right)$ lebih tinggi dari kelompok anak yang diberi metode pembelajaran kompetitif $\left(\mathbf{A}_{2}\right)$.

Hal ini terlihat dari rata-rata perolehan anak yang belajar metode kooperatif mencapai 142,875 lebih tinggi dari pada anak yang belajar dengan metode kompetitif yakni 132,275. Perbedaan hasil ini terjadi karena dalam metode belajar kooperatif adalah metode belajar yang sarat dengan muatan kegiatan yang mengarah kepada keterampilan sosial seperti saling tolong menolong, saling kerjasama, berdiskusi, dan saling bertanggung jawab. Kesulitan di dalam pembelajaran dapat dicari pemecahannya secara bersama-sama. Jika anak mengalami kesulitan dalam mengerjakan tugas yang diberikan, maka anggota yang lain dapat membantu temannya mengarahkan dalam mengerjakan tugas. Susunan bangku anak yang belajar kooperatif yang dirancang berkelompok terdiri 4-5 orang duduk saling berhadapan.

Pada metode pembelajaran kompetitif, anak tidak saling tergantung, individualistik, di mana anak akan bekerja sendiri-sendiri, tanpa ada ketergantungan dengan lainnya. Susunan bangkunya disusun berbaris saling berhadapan terdiri beberapa anak. Tugas diselesaikan sendiri, tanpa ada keterkaitan dengan tugas teman dibangku sebelahnya. Anak berkosentrasi pada tugas masing-masing, sesekali berkomunikasi dengan teman yang berada dibangku sebelahnya, saling meminjam peralatan belajar akan tetapi masing-masing kosentrasi pada tugasnya secara individual. Berdasarkan perbedaan dua metode belajar tersebut, maka diduga metode belajar kooperatif lebih efektif dalam mengembangkan keterampilan sosial, jika dibandingkan dengan metode belajar kompetitif.

2. Hasil keterampilan sosial anak untuk kelompok anak yang memiliki tipe pengasuhan orang tua dengan kategori autoritatif $\left(B_{1}\right)$ lebih tinggi dari kelompok 
tipe pengasuhan orang tua kategori permisif $\left(\mathbf{B}_{2}\right)$.

Rata-rata perolehan anak dari tipe pengasuhan autoritatif mencapai 141,4 lebih tinggi dari pada anak dari tipe pengasuhan permisif yakni 133,76. Hal ini didasarkan karena anak dari tipe pengasuhan autoritatif menurut Baumrind, lebih kompoten secara sosial, senang bergaul dan berteman, senang bermain bersama, bekerja bersama-sama mengerjakan tugas, suka menolong orang dan bertanggung jawab. Anak yang dibesarkan oleh orang tua autoritatif, cenderung menjadi mandiri dan matang dalam interaksi sosial, sedangkan anak dari tipe pengasuhan permisif tidak kompeten secara sosial, kurang suka menjalin kontak dengan orang lain, sehingga sulit menyusaikan diri secara sosial, cenderung kurang kontrol diri dan bertindak sekehendak hatinya. Dengan demikian, dapat dikatakan bahwa anak dari tipe pengasuhan orang tua autoritatif, lebih terampil secara sosial dibanding anak dari permisif.

3. Interaksi antara dua faktor metode pembelajaran (A) dan tipe pengasuhan orang tua anak (B) mempunyai pengaruh yang signifikan terhadap hasil keterampilan sosialanak usia dini.

Anak dengan tipe pengasuhan yang autoritatif memiliki karakteristik yang lebih mampu mendukung terselenggaranya metode belajar kooperatif dibanding anak dengan tipe pengasuhan permisif. Anak dengan tipe pengasuhan autoritatif memiliki ciri-ciri, mudah bergaul, banyak teman, tidak bersikap kasar, sopan/rasa hormat, empati, bertanggung jawab, dan lain-lain. Karakteristik yang demikian jika belajar dengan metode kooperatif maka akan lebih efektif baik secara akademis maupun dalam perolehan keterampilan sosial seperti kerjasama, toleransi, berempati, simpati, dan menghargai orang lain. Sedangkan anak dengan tipe pengasuhan yang permisif dengan karakteristik lebih agresif, nakal, egois, enferioritas, dan kurang suka menjalin kontak dengan orang lain memang lebih tepat apabila menggunakan metode belajar kompetitif. Mereka belajar sendiri tanpa ketergantungan dengan kelompok lain. Hasil belajar pun dinilai secara perorangan. Dalam pembelajaran kompetitif juga diajarkan keterampilan sosial, seperti bersikap jujur, adil dan sportif, akan tetapi tidak seluas dengan pembelajaran keterampilan sosial yang ada dalam metode pembelajaran kooperatif.

Berdasarkan hasil penelitian ini, diperoleh bahwa ada pengaruh interaksi dua faktor tipe pengasuhan orang tua dan metode pembelajaran mempunyai pengaruh yang signifikan terhadap hasil keterampilan sosial anak usia dini, yang berarti kombinasi antara kedua faktor tersebut, dapat memberikan bentuk pembelajaran yang memadai.

4. Khusus tipe pengasuhan orang tua kategori autoritatif, hasil keterampilan sosial anak dalam kelompok metode pembelajaran kooperatif lebih tinggi dari kelompok metode pembelajaran kompetitif.

Hal ini terlihat dari rata-rata perolehan keterampilan sosial anak dari tipe pengasuhan autoritatif yang diberi metode pembelajaran kooperatif mencapai 150,15 lebih tinggi dari pada diberi metode pembelajaran kompetitif yakni 132,65, karena tipe pengasuhan yang autoritatif, memiliki karakteristik yang lebih mampu mendukung terselenggaranya metode belajar kooperatif.

Anak dengan tipe pengasuhan autoritatif memiliki ciri-ciri, mudah menyesuaikan diri, menyukai tantangan, mandiri, bertanggung jawab, empati, optimis, banyak teman, kemampuan berkomunikasi dan mengharapkan prestasi terbaik. Karakteristik yang demikian jika belajar dengan metode kooperatif, maka akan lebih efektif baik secara akademis maupun dalam perolehan keterampilan sosial seperti berempati, simpati, mengontrol diri, kerjasama dan bertanggungjawab, yang akan membentuk anak menjadi anak yang berkepribadian sosial yang lebih baik. Sedangkan anak dengan tipe pengasuhan yang autoritatif kurang tepat dengan metode belajar kompetitif yang cenderung kurang efektif dalam meningkatkan keterampilan sosial anak. Anak yang memiliki tipe pengasuhan autoritatif dimungkinkan akan meningkat keterampilan sosialnya, apabila mereka belajar dengan metode kooperatif, anak mendapat kesempatan untuk saling berempati, saling bersimpati, mengontrol diri, kerjasama, dan bertanggungjawab terhadap anggota kelompok atau terhadap teman sebayanya.

5. Khusus tipe pengasuhan orang tua kategori permisif, hasil keterampilan sosial anak dalam kelompok metode pembelajaran kooperatif lebih tinggi dari 


\section{kelompok metode pembelajaran kompetitif.}

Data menunjukkan, bahwa rata-rata anak tipe pengasuhan orang tua kategori permisif, apabila diberi metode pembelajaran kooperatif keterampilan sosialnya mencapai 135,60 lebih tinggi, dari pada diberi metode pembelajaran kompetitif dengan rata-rata 131,90. Metode pembelajaran kooperatif memiliki kemampuan dalam meningkatkan keterampilan sosial anak, sehingga walaupun kedua metode pembelajaran ini didesain dengan muatan yang sama akan tetapi unsur-unsur keterampilan sosial tersebut lebih besar peluang terealisasi dalam metode pembelajaran kooperatif.

Treatmen pembelajaran diberikan kepada anak sama, baik dari pengasuhan autoritatif maupun kompetitif selama 2 minggu secara kontinyu. Selama itu pula anak saling berinteraksi antara satu dengan yang lain. Anak khususnya usia 4-6 tahun menurut Piaget sudah mampu berpikir secara simbolis; mampu melakukan partisipasi dalam berbagai kegiatan; mampu mengambil inisiatif untuk suatu tindakan yang akan dilakukan; dan mampu melihat dari perspektif orang lain. Jadi, faktor lingkungan memiliki peran yang sangat besar dalam pembentukan keterampilan sosial. Anak belajar menolong karena melihat contoh atau metode yang diperlihatkan oleh orang yang berada disekitarnya. Hal ini sesuai yang dikatakan Bandura bahwa anak dikenal sebagai peniru ulung, seperti meniru pembicaraan atau tindakan yang dilihatnya.

Berbeda dengan metode pembelajaran kompetitif, di mana anak sangat terbatas dalam melakukan interaksi sosial dengan temannya, tidak sama dengan metode pembelajaran kooperatif yang diberikan kebebasan dalam berhubungan sosial dengan yang lainnya. Anak saling bekerjasama, berkomunikasi dan saling memberikan bantuan kepada teman yang membutuhkan.

\section{SIMPULAN DAN SARAN}

\section{Simpulan}

Simpulan dari penelitian ini yaitu hasil keterampilan sosial anak untuk kelompok anak yang diberi metode pembelajaran kooperatif, lebih tinggi dari kelompok anak yang diberi metode pembelajaran kompetitif. Hal ini didasarkan karena metode belajar kooperatif lebih efektif dalam mengembangkan keterampilan sosial, jika dibandingkan dengan metode belajar kompetitif.

Hasil keterampilan sosial anak untuk kelompok anak yang memiliki tipe pengasuhan orang tua dengan kategori autoritatif, lebih tinggi dari kelompok tipe pengasuhan orang tua kategori permisif. Hal ini didasarkan karena anak dari tipe pengasuhan orang tua autoritatif, lebih terampil secara sosial dibanding anak dari permisif.

Terdapat pengaruh interaksi antara faktor tipe pengasuhan orang tua dengan metode pembelajaran terhadap keterampilan sosial anak. Berdasarkan hasil penelitian diperoleh bahwa ada pengaruh interaksi dua faktor tipe pengasuhan orang tua dan metode pembelajaran mempunyai pengaruh yang signifikan terhadap hasil keterampilan sosial anak usia dini, yang berarti kombinasi antara kedua faktor tersebut, dapat memberikan bentuk pembelajaran yang memadai.

Tipe pengasuhan orang tua kategori autoritatif, hasil keterampilan sosial anak yang diberi metode pembelajaran kooperatif, lebih tinggi dari metode pembelajaran kompetitif. Hal ini didasarkan karena anak dengan tipe pengasuhan yang autoritatif kurang tepat dengan metode belajar kompetitif yang cenderung kurang efektif dalam meningkatkan keterampilan sosialnya. Anak yang memiliki tipe pengasuhan autoritatif dimungkinkan akan meningkat keterampilan sosialnya, apabila mereka belajar dengan metode kooperatif, anak mendapat kesempatan untuk saling berempati, saling bersimpati, mengontrol diri, kerjasama, dan bertanggung jawab terhadap anggota kelompok atau terhadap teman sebayanya.

Tipe pengasuhan orang tua kategori permisif, hasil keterampilan sosial anak yang diberi metode pembelajaran kooperatif, lebih tinggi dari pada metode pembelajaran kompetitif. Hal ini didasarkan bahwa metode pembelajaran kooperatif memiliki kemampuan dalam meningkatkan keterampilan sosial anak, sehingga walaupun kedua metode pembelajaran ini didesain dengan muatan yang sama akan tetapi unsur-unsur keterampilan sosial tersebut lebih besar peluang terealisasi dalam metode pembelajaran kooperatif, dibanding metode pembelajaran kompetitif di mana anak sangat terbatas dalam melakukan interaksi sosial dengan temannya. 


\section{Saran}

Dalam rangka upaya meningkatkan keterampilan sosial anak, maka ada beberapa saran yang terkait, yaitu:

1. Kepada guru diharapkan lebih mengoptimalkan penerapan metode kooperatif didalam proses kegiatan pembelajaran guna meningkatkan keterampilan-keterampilan sosial anak.

2. Kepada orang tua diharapkan dapat meningkatkan kualitas pengasuhannya dengan menerapkan pola pengasuhan demokratis/autoritatif yang terbukti lebih kompeten secara sosial didalam berempati, bekerjasma, berkomunikasi,kontrol diri dan bertanggungjawab.

3. Kepada kepala sekolah diharapkan dapat memfasilitasi kerjasama dengan semua elemen yang terkait dengan anak yakni, guru, orang tua murid, staf administrasi dan pembantu sekolah, agar semua elemen ini dapat menjadi role model yang baik, melakukan intensitas komunikasi dan kerjasama yang baik dalam menangani perkembangan keterampilan sosial anak.

4. Kepada para peneliti yang berminat melakukan penelitian lanjutan dengan melakukan model penelitian yang berbeda, agar dapat diketahui model mana yang paling efektif dalam meningkatkan keterampilan sosial anak

\section{DAFTAR PUSTAKA}

Alwi, Hasan. dkk. 2002. Kamus Besar Bahasa Indonesia Edisi Ketiga. Jakarta: Balai Pustaka, Pusat Bahasa Departemen Nasional.

Undang-Undang Nomor 20 Tahun 2003 Tentang Sistem Pendidikan Nasional. Jakarta: Departemen Pendidikan Nasional.

Elizabeth B. Hurlock. 1992. Perkembangan Anak Jilid 2, Alih Bahasa: Meitasari, T Jakarta.

-2000. “Perkembangan Anak” Jilid 1.Terjemahan oleh Meitasari Tjandra dan Muslichah Zakarsih Jakarta: Erlangga.

Gerlach dan Donald P. Ely. 2008. Pengaruh Metode Pembelajaran dan Gaya Kognitif Terhadap Hasil Belajar Ilmu
Kimia di SMU" Sinopsis Disertasi, Universitas Negeri Jakarta.

Goodwin, W. Marilyn. 1999.“ Cooperative Learning and Social Skills: What Skills to Teach and How to Teach Them" Intervention in School and Clinic, 35 (1).

Hargie, Owen. 2006. Social Skills In Interpersonal Communication Third Edition. British: British Library In Publication Data.

Johnson, W. David, Johnson, T. Roger. 1999. Learning Together and Alone, Cooperative, Competitive, and Indivudualistic Learning. Third Edition. Massachusets: Allyn and Bacon Publisher.

Morrison, S George. 2012. Dasar-Dasar Pendidikan Anak Usia Dini. Jakarta, Indeks.

Lwin, May et, al. 2008. How to Multiply your Child,s Intelligence, alih Bahasa Cristine Sujana. Yogyakarta, Indeks.

Rogers, S Cosby. and Janet K. Sawyers. 2009. Play In The Lives of Children. Washington, DC: Printed The United States of America.

Salkind, J Neil. 2009. Teori-Teori Perkembangan Manusia: Sejarah Kemunculan, Konsepsi Dasar, Analisis Komparatif, dan Aflikasi. Bandung: Nusamedia.

Santoso, Soegeng. 2002. Pendidikan Anak Usia Dini, Pidato Pengukuhan Guru Besar Tetap Fakultas Ilmu Pendidikan. Jakarta.

Santrock, W. John. 2008. Masa Perkembangan Anak, Edisi ke 11. Jakarta: Salemba Humanika.

-2011. Psikologi Pendidikan, Edisi kedua. Jakarta: Kencana.

Selvarajah, Christopher. 2010. The Impact of Social Motivation On Cooperative Learning and Assessment Preferences, Journal of Management \& Organization, 16 (1). 